\title{
TINJAUAN HUKUM INTERNASIONAL HAM DAN HUKUM ISLAM TERHADAP LGBT PERSPEKTIF HUMAN DIGNITY MASHOOD A. BADERIN
}

\author{
Abu Dzarrin al-Hamidy \\ Universitas Islam Negeri Sunan Ampel Surabaya, Indonesia \\ E-mail: adzarrin2015@gmail.com
}

\begin{abstract}
This article deals with the issue of homosexuality from the perspective of human rights international law and Islamic law, particularly in the view of Mashood Baderin. The result of understanding towards human rights international law as well as towards Islamic law as the blessings for the universe places human beings in the most respected position. However, there emerge the phenomenon of non-mainstream sexual orientation, such as lesbian, gay, bisexual and transgender (LGBT). In the perspective of Mashood Baderin, who portrays human rights international law and Islamic law on the principles of equality and justice, these LGBTs have their rights, as they are also human beings that should be respected due to their human dignity. It is inhumane to discriminate and condemn them. They should receive proportional treatment from the state so that their civil rights are guaranteed. However, with regard to their sexual orientation Islamic law prohibits the same sex marriage or other forbidden sexual relations.
\end{abstract}

Keywords: Human rights international law; Islamic law; LGBT; margin of appreciation.

\section{Pendahuluan}

Pada tanggal 19 April 1981 masyarakat Indonesia dikejutkan dengan pemberitaan perkawinan dua wanita lesbian yang digelar di pub daerah Blok M Jakarta Selatan dan dihadiri sekitar 120 undangan. Peristiwa ini menjadi pemberitaan menghebohkan di kalangan masyarakat, bahkan tidak sedikit yang mengutuknya. Anehnya, pengamat homoseksual Barat, Tom Boellstorff dalam bukunya The Gay Archipelago, Sexuality, and Nation in Indonesia, justru memuji 
keberanian pasangan ini dan menobatkannya sebagai pejuang yang berani membela hak-hak lesbian yang harus diakui publik Indonesia. ${ }^{1}$

Saat Patrialis Akbar menjabat sebagai Menteri Hukum dan Hak Asasi Manusia, sekelompok masyarakat yang memiliki kelainan orientasi seksual secara lebih berani menuntut pengadaan ruang untuk berhubungan seks di penjara khusus untuk narapidana lesbian, gay, biseksual, dan transgender (LGBT). Seperti orang yang telah terputus urat malunya, dengan lantangnya mereka berkata, "Bagaimanapun, LGBT memiliki hak untuk menyalurkan hasrat biologisnya". ${ }^{2}$

Masyarakat Indonesia juga pernah dihebohkan dengan kehadiran praktisi lesbian dari Kanada, Irshad Manji, untuk launching buku terbarunya, sekaligus ingin menyadarkan bangsa Indonesia bahwa tidak ada yang salah dengan orientasi seksual sesama jenis. Kehadiran tokoh lesbi yang berkedok launching buku dan diskusi ini memancing kemarahan ormas-ormas Islam. Bagaimana tidak, lebih jauh ia menahbiskan dirinya sebagai seorang reformis (mujaddidab). "I'm not a moderate Muslim, I'm a reformist", katanya dalam situs resminya. Baginya, Muslim moderat dinilai masih tidak cukup berani menghadapi ortodoksi keagamaan, sehingga dia pun menyerukan reformasi (tajdîd) pemikiran dalam Islam. ${ }^{3}$

Fenomena di atas tentu menyulut kemarahan bahkan sentimen sosial, kultur, dan keagamaan sebagian besar masyarakat Indonesia yang dikenal sebagai bangsa religius. Pada akhirnya mereka menolak kehadiran kelompok LGBT di tengah-tengah kehidupan masyarakat. Di pihak lain, penulis memberanikan diri untuk menarik kesimpulan, itulah mengapa ormas-ormas Islam di Indonesia tidak memberi ruang sedikit pun—setidaknya untuk sementara ini-untuk tidak mengkaji secara komprehensif dalam diskusi-diskusi ilmiah (ḅalâqab) guna melihat sisi "kemanusiaan" (bumanity) kelompok LGBT selain menolak begitu saja kehadirannya dengan berlindung di balik alasan stabilitas nasional?. ${ }^{4}$

\footnotetext{
${ }^{1}$ Henri Shalahuddin, "Menyongsong Kebangkitan Kaum Nabi Luth di Indonesia" dalam http://thisisgender.com/9-Februari-2015/diakses 21 November 2015.

2 Ibid.

${ }^{3}$ Ibid.

${ }^{4}$ Menurut Dede Oetomo (doktor bidang linguistik dari Cornell University, Amerika Serikat yang pada tahun 1982 mendirikan organisasi LGBT pertama di Indonesia bernama Lambda di Solo), sampai saat ini di Indonesia tidak dijumpai perlindungan antidiskriminasi yang secara spesifik menyebutkan perlindungan untuk LGBT. Padahal beberapa kota di Filipina sudah ada peraturan daerah yang secara khusus
} 
Pada intinya, kertas kerja ini ingin membatasi diskusi tentang LGBT dari sisi kemanusiaannya (karâmah insânŷyah) seperti yang tertuang dalam hukum internasional HAM maupun Hukum Islam dalam perspektif buman dignity Mashood A. Baderin, bukan pada perilaku sosialnya yang dianggap menyimpang. Ujung dari diskusi ini ingin melahirkan kesimpulan, apakah kelompok LGBT harus dieksekusi ataukah harus diperlakukan sebagai "pengidap kelainan" yang perlu direhabilitasi dan mendapat perhatian khusus dari penyelenggara negara sebagaimana pecandu narkoba dan obat-obatan terlarang lainnya. Ataukah mereka harus diberdayakan sebagai kelompok biasa (as usual) yang keberadaannya diakui, sehingga hakhak sipil mereka tetap melekat sebagaimana mestinya.

\section{Hukum Internasional Hak Asasi Manusia (HIHAM)}

Hak asasi manusia adalah hak semua manusia dalam kesetaraan penuh. Hak asasi manusia ini berasal dari "martabat inheren manusia" (inherent dignity of the buman person) dan didukung oleh suatu teori yang berpusat pada perikemanusiaan manusia, pada manusia sebagai manusia, dan anggota umat manusia. Statemen-statemen ini berkaitan dengan standar-standar kehidupan yang tiap-tiap manusia mempunyai hak untuk mendapatkannya dari masyarakat sebagai manusia. ${ }^{5}$ Mashood A. Baderin juga mengutip ungkapan Umozurike yang menyatakan bahwa hak asasi manusia adalah serangkaian klaim tanpa terkecuali yang didukung oleh etika dan yang semestinya didukung oleh hukum yang diajukan kepada masyarakat, terutama diajukan

melindungi LGBT. Tidak ada undang-undang ataupun peraturan di Indonesia yang memberikan perlindungan secara khusus bagi LGBT dengan menyebutkan kata 'LGBT' misalnya, kecuali di Undang-Undang Dasar 1945, dan itu pun sifatnya sangat umum. Pemerintah juga belum secara resmi mengungkapkan bahwa semua golongan, termasuk LGBTI (Lesbian, Gay, Biseksual, Transgender, dan Interseks) adalah warga yang harus dilindungi. Kementerian Hukum dan Hak Asasi Manusia juga setengah-setengah kalau bicara soal LGBT. Menteri Pemberdayaan Perempuan dan Perlindungan Anak Yohana Yembise juga belum pernah secara resmi membicarakan hak-hak kaum lesbian. Ini berbeda dengan lembaga-lembaga nonpemerintah, seperti Komisi Nasional (Komnas) HAM dan Komisi Nasional AntiKekerasan terhadap Perempuan yang sudah mulai terbuka membicarakan LGBT. Mereka sudah bisa memberikan pernyataan dan program nyata. Begitulah kira-kira perkembangan Indonesia sejauh ini. Lihat Dede Oetomo, "Pemerintah Dinilai Tak Dukung LGBT Karena Enggan Rugi" dalam http://www.cnnindonesia.com/1Mei-2015/diakses 21 November 2015.

5 Mashood. A. Baderin, International Human Rights And Islamic Law (New York: Oxford University Press, 2003), 16. 
kepada para pengelola negara oleh individu-individu atau kelompokkelompok berdasarkan kemanusiaan mereka. Hak-hak itu berlaku terlepas dari ras, warna kulit, jenis kelamin, atau pembeda lain, dan tidak mungkin ditarik kembali atau ditolak oleh semua pemerintahan, rakyat, ataupun individu. ${ }^{6}$

Dalam perkembangannya, HAM menjadi sebuah tren global yang semakin menempati posisi penting dalam pola hubungan antara individu dengan masyarakat dunia. HAM seolah menjadi sebuah janji bagi terpeliharanya hak-hak individu dan pencapaian kehidupan yang baik bagi manusia. Lahirnya HAM ini tidak bisa dilepaskan dari pergolakan manusia modern yang harus menghadapi pengaturan negara dan semakin meningkatnya kesadaran akan fungsi negara bagi perlindungan individu. ${ }^{7}$

${ }^{6}$ Ibid., 16-17.

7 Tholhatul Choir dan Ahwan Fanani (eds.), Islam dalam Berbagai Pembacaan Kontemporer (Yogyakarta: Pustaka Pelajar, 2009), 325. Pengertian HAM menurut Jan Materson dari Komisi Hak Asasi Manusia PBB adalah hak-hak yang melekat pada manusia, yang tanpa dengannya manusia mustahil dapat hidup sebagai manusia. HAM terdiri dari dua hak dasar yang paling fundamental, yaitu "hak persamaan" dan "hak kebebasan". Lahirnya HAM sendiri dimulai dengan lahirnya Magna Charta pada tahun 1215 di Inggris. Magna antara lain mencanangkan bahwa raja yang tadinya memiliki kekuasaan absolute (raja yang menciptakan hukum tetapi dia sendiri tidak terikat pada hukum) menjadi dibatasi kekuasaannya dan mulai dapat dimintai pertanggung jawaban di muka hukum. Lahirnya Magna Charta ini kemudian diikuti oleh perkembangan yang lebih konkret dengan lahirnya Bill of Rights di Inggris tahun 1689. Pada masa itu mulai timbul adagium yang intinya bahwa manusia sama di depan hukum (equality before the law). Untuk mewujudkan semua itu, lahirlah teori Rousseau tentang Contract Social. Montesquieu dengan Trias Politika mengajarkan pemisahan kekuasaan guna mencegah tirani, John Locke di Inggris, dan Thomas Jefferson di AS dengan hak-hak dasar kebebasan dan persamaan yang dicanangkan. Perkembangan HAM selanjutnya ditandai munculnya The American Declaration of Independence yang lahir dari paham Rousseau dan Montesquieu. Selanjutnya pada tahun 1789 lahirlah The French Declaration, di mana hak-hak lebih dirinci dan melahirkan dasar The Rule of Law yang berisi tidak boleh ada penangkapan dan penahanan yang semena-mena, termasuk ditangkap tanpa alasan yang sah dan ditahan tanpa surat perintah dan dipertegas juga dengan freedom of expression (kebebasan mengeluarkan pendapat), freedom of religion (kebebasan menganut agama/keyakinan yang dikehendaki), dan the right of property (perlindungan terhadap hak milik). Perlu diketahui The Four Freedoms dari Presiden Roosevelt yang dicanangkan pada tanggal 6 Januari 1941 berisikan: (1) kebebasan berbicara dan menyatakan pendapat; (2) kebebasan memeluk agama dan beribadah; (3) kebebasan dari kemiskinan; dan (4) kebebasan dari ketakutan. Dasar pemikiran keseluruhan tersebut melahirkan rumusan HAM yang bersifat universal, yang kemudian dikenal dengan The Universal Declaration of Human Rights yang dideklarasikan PBB pada tahun 
Meskipun ada yang melacak genealogi HAM sampai pada magna charta di Perancis, namun HAM sebagai sebuah deklarasi universal tetaplah fenomena yang lahir bersama dengan fenomena negara modern. Pernyataan mengenai hak-hak manusia oleh para founding father Amerika adalah momentum paling jelas yang menggambarkan artikulasi HAM ke dalam sebuah komitmen bernegara. Sebagai perangkat peraturan secara internasional, tidak dapat disangkal bahwa bibit-bibit dan etos utama HAM, khususnya hak sipil politik, adalah berasal dari Barat. ${ }^{8}$

Bassam Tibi menyatakan bahwa HAM adalah hak-hak individu yang lahir dari pemikiran modern Eropa mengenai hukum alam (natural law). Hak-hak tersebut diangkat oleh negara-negara Eropa sebagai standar institusi hukum. Dari situlah Deklarasi Universal mengenai Hak-hak Asasi Manusia (DUHAM) PBB pada tahun 1948 berasal, dan HAM menjadi hukum Internasional. ${ }^{9}$

Keberadaan HAM sebagai hukum internasional, mengubah pola hubungan negara dan individu. Pola hubungan pra-HAM diwarnai dengan otoritas negara atas individu, di mana negara banyak dikuasai oleh pemimpin otoriter. Dalam masyarakat tradisional, kekuasaan raja bersifat absolut. Ia memiliki kekuasaan besar terhadap individu. Individu harus mengabdi kepada kekuasaan dan dengan ketaatan kepada kekuasaan itulah dia mendapat perlindungan. Apabila individu membahayakan kekuasaan, dia dapat dieliminasi sebagai perlindungan terhadap kekuasaan yang mengklaim diri sebagai pengejawantahan kepentingan kolektif. ${ }^{10}$ Oleh karena itu, subjek utama masyarakat internasional secara tradisional adalah negara. Negara merupakan institusi yang mampu mempresentasikan diri sebagai anggota masyarakat internasional. Hanya negara yang dapat terlibat dan

1948. Lihat Baharuddin Lopa, Al-Qur'ân dan Hak-hak Asasi Manusia (Yogyakarta: Dana Bhakti Prima Yasa, 1999), 2-4.

${ }^{8}$ Hak Asasi Manusia (HAM) yang menjadi produk politik PBB secara umum terbagi menjadi dua arus, yaitu HAM dalam bidang sipil politik dan HAM dalam bidang sosial budaya. HAM sipil politik banyak dipengaruhi oleh negara-negara maju Barat, sementara HAM sosial-budaya merupakan aspirasi negara-negara dunia ketiga.

9 Bassam Tibi, "Islamic Law/Syariah and Human Rights: International Law and International Relations" dalam Tori Lindholm and Kari Vogt (eds.), Islamic Law Reform and Human Rights: Challenges and Rejoinders (Oslo: Nordic Human Rights Publications, 1993), 75.

${ }^{10}$ Choir dan Fanani (eds.), Islam dalam Berbagai Pembacaan, 326. 
menjadi subjek dalam hukum Internasional. ${ }^{11}$ Konsep Hak Asasi Manusia (HAM) yang mempengaruhi setiap aspek hubungan internasional dan melintasi setiap aspek hukum internasional kontemporer menjadi tujuan utama internasional Perserikatan BangsaBangsa (PBB). Demikian pula, organisasi antar-pemerintah daerah juga mengakui adanya ide hak asasi manusia dan berbagai pelanggaran HAM yang terjadi. Perlindungan hak asasi manusia telah menjadi alat ampuh yang secara universal dapat menembus "tirai suci" kedaulatan negara demi menjaga martabat manusia. ${ }^{12}$

\section{Sketsa Biografi Mashood A. Baderin}

Mashood A. Baderin merupakan Guru Besar Hukum dan Kepala Sekolah Hukum di Sekolah Studi Oriental dan Afrika (the School of Oriental and African Studies/SOAS), University of London. Dia sebelumnya Profesor Hukum di Sekolah Hukum Brunel, Brunel University, Uxbridge, London Barat. Ia adalah Reader dalam Hukum Hak Asasi Manusia Internasional dan Direktur Hukum Internasional dan HAM. Unit Hak Asasi, Sekolah Hukum, Universitas Inggris Barat, Bristol. Dia juga sebelumnya mengajar hukum di Sekolah Hukum, Universitas Nottingham, dan Sekolah Hukum Universitas Southampton, dan menjadi Profesor Tamu di Amerika, Universitas Paris, Paris, Perancis, dan Universitas Sains Islam Malaysia, Nilai, Malaysia. Beliau juga adalah barrister (pengacara) berkualitas dan berpengalaman dan Solicitor Agung Pengadilan Nigeria. Dia adalah pendiri co-editor Jurnal Muslim Dunia Hak Asasi Manusia. ${ }^{13}$

Baderin melakukan berbagai penelitian di bidang Hukum Islam, Hukum Internasional, dan Perbandingan Hukum Hak Asasi Manusia, dan Hukum Islam. Dia juga berperan sebagai konsultan Hak Asasi Manusia dan Hukum Islam untuk departemen dan lembaga pemerintahan yang berbeda, dan telah diundang untuk menyajikan makalah mengenai bidang riset di berbagai konferensi nasional dan internasional, lokakarya serta seminar. Pendek kata, spesialisasi keahlianya adalah tentang HAM dan keterkaitannya dengan sharî́ah Islam (Islamic law). International Human Rights and Islamic Law adalah buku monumental Mashood. Buku tersebut berasal dari disertasi Ph.D yang ditempuh di Universitas Nottingham pada tahun 2001. Di samping menjadi professor hukum, Baderin juga aktif di berbagai

\footnotetext{
11 Ibid., 327.

12 Baderin, Internasional Human Rights, 1.

${ }^{13}$ http://works.bepress.com/mashood_baderin/diakses 24 Juli 2016.
} 
even-even internasional terutama yang terkait dengan permasalahan Hak Asasi Manusia (HAM) dan dunia Islam. Pada 23 Maret 2012, Baderin terpilih menjadi The United Nations Independent Expert (Penasehat atau staf ahli Independen PBB) untuk menangani situasi HAM di Sudan. Hasil tugas ini diserahkan Baderin ke majelis HAM Perserikatan Bangsa-Bangsa (the UN Human Rights Council/HRC). ${ }^{14}$

Karya-karya Baderin terdiri dari beberapa buku dan artikel, bukubukunya antara lain International Human Rights and Islamic Law (2003 dan 2005), Economic, Social and Cultural Rights In Action (dengan Robert McCorquodale) 2007, International Law and Islamic Law (2008), Islam and Human Rights: Selected Essays of Abdullah an-Naim (2010) and International Human Rights Law: Six Decades After The UDHR and Beyond (dengan Manisuli Ssenyonjo) (2010). Sedangkan artikel yang ia tulis antara lain The Evolution of Islamic Law of Nations and The Modern International Order: Universal Peace Through Mutuality and Cooperation (The American Jurnal of Islam and Social, 2000), Editors' note to Inangural Issue of The Muslim World Journal of Human Rights (dengan Shadi Mokhtari, Mahmood Monshi Pouri dan Lynn Wecchman) pada tahun 2004. Editors' note to The Special Issue (dengan Shadi Mokhtari, Mahmood Monshi Pouri dan Lynn Wecchman) pada tahun 2005. A. Comparative Analysis of the Rights to a fair trial and due process under international Human Rights Law and Saudi Arabian Domestic Law. (International Journal of Human Rights, 2006). Effective Legal Respresentation in Syariah Courts as a Means of Addressing Human Rights Concerns in The Islamic Criminal Justice System of Muslim States. (Year book of Islamic and Middle Eastern Law, 2006). Islam and the Realization of Human Rights in The Muslim World: A Reflection on Two Essential Approaches and Two Divergent Perspectives. (Muslim World: Journal of Human Rights, 2007). Religion and International Law: Friend or Foes? (European Human Rights Law Review, 2009). ${ }^{15}$

\section{Dialektika Hukum Internasional HAM dan Hukum Islam}

Dalam kaitannya dengan topik utama diskusi tentang LGBT seperti yang dibicarakan dalam tulisan ini, apa yang berlaku di dunia internasional (baca: Barat) dengan apa yang berjalan di dunia Islam, kalau menyangkut konsep dasar tentang HAM sudah tidak ada

\footnotetext{
14 Ibid. Lihat juga http://www.soas.ac.uk/staff/staff30601.php, diakses 24 Juli 2016.

15 http://www.oup.com/us/catalog/general/subject/Law/PublicInternationalLaw /InternationalHumanRights, diakses 24 Juli 2016.
} 
masalah. Namun dalam realitas di antara kedua pihak itu seringkali tidak sejalan dalam kenyataan. Karena itu, menurut Halliday, seperti juga dikutip Baderin, ${ }^{16}$ setidaknya ada empat tanggapan atau sikap umat Islam yang memperdebatkan tentang hak asasi manusia internasional, yaitu:

a. Islam kompatibel dengan hak asasi manusia (HAM) internasional.

b. Hak asasi manusia sebenarnya hanya dapat sepenuhnya direalisasikan di bawah hukum Islam.

c. HAM internasional merupakan agenda imperialis yang harus ditolak.

d. HAM internasional tidak sesuai dengan agama Islam. ${ }^{17}$

Namun menurut Mortimer, masih terdapat satu sikap yang terlewatkan oleh Halliday, yaitu bahwa tujuan HAM internasional memiliki agenda tersembunyi, yakni anti-agama. ${ }^{18}$

Bila dilihat secara kritis, sebagian besar tanggapan masyarakat Muslim merupakan reaksi terhadap apa yang sering digambarkan sebagai standar ganda negara-negara Barat dengan dalih hak asasi manusia internasional. Tanggapan mereka mencerminkan adanya upaya penyelewengan tentang hak asasi manusia antara aspek kemanusiaan dan politik internasional ketimbang penegasian atas konsep HAM dalam Hukum Islam. Karena itu selanjutnya akan dievaluasi tanggapan-tanggapan tersebut dengan menggunakan parameter hukum Islam.

Pandangan pertama, Islam kompatibel dengan hak asasi manusia adalah yang paling dapat dipertahankan di dalam prinsip-prinsip hukum Islam. Hal ini bukan hanya dalam membaca gagasan Barat tentang hak asasi manusia ke dalam prinsip-prinsip Islam. Sumber dan metode hukum Islam mengandung prinsip-prinsip umum pemerintahan yang baik dan kesejahteraan manusia yang memvalidasi cita-cita modern internasional hak asasi manusia. Menghormati keadilan, perlindungan terhadap kehidupan manusia dan martabat, adalah prinsip-prinsip utama yang melekat pada sharî̀ah. Ini adalah tujuan keseluruhan sharî‘ah yang merujuk kepada al-Qur'ân, surah alNaḥl ayat 90, disebutkan bahwa: Sesunggubnya Allah menyuruh (kamu)

\footnotetext{
16 Ibid., 11-12.

${ }^{17}$ F. Halliday, "Relativism and Universalism in Human Rights: The Case of the Islamic Middle East", dalam D. Beetham (ed.), Politics and Human Rights (Oxford: Blackwell, 1995), 152.

${ }^{18}$ E. Mortimer, "Islam and Human Rights", Index on Censorship, No. 12 (Oktober, 1983), 5.
} 
berlaku adil dan berbuat kebajikean, memberi kepada kaum kerabat, dan Allah melarang dari perbuatan keji, kemungkaran dan permusuban. Dia memberi pengajaran kepadamu agar kamu dapat mengambil pelajaran. ${ }^{19}$

Pandangan kedua, hak asasi manusia yang benar hanya dapat dilaksanakan sepenuhnya di bawah hukum Islam. Islam tidak egosentris sehubungan dengan hal-hal duniawi tetapi lebih mendorong kerjasama (ta'âwun) untuk pencapaian kesejahteraan manusia. Islam mendorong interaksi dan berbagi persepsi. Tradisi Nabi Muhammad menganjurkan bagi umat Muslim untuk mencari ilmu sampai ke negeri Cina (sebuah negara non-Muslim). ${ }^{20}$

Pandangan ketiga, hak asasi manusia internasional merupakan agenda imperialis yang harus ditolak. Pendapat ini populer dalam wacana hak asasi manusia dari semua negara berkembang. Ini merupakan ketakutan terhadap paham neo-kolonialisme, dan merupakan efek psikologis dari pengalaman masa lalu kolonial negaranegara berkembang terhadap imperialisme Barat. Ketakutan itu kadang-kadang diperkuat oleh desakan bangsa Barat atas didefinisikannya hak asasi manusia hanya dalam perspektif Barat tanpa mempertimbangkan kontribusi dan pemahaman tentang budaya lain.

Jika kita memahami hak asasi manusia internasional secara keseluruhan sebagai tujuan kemanusiaan secara universal untuk melindungi individu terhadap penyalahgunaan wewenang negara dan untuk peningkatan martabat manusia, maka pandangan bahwa Islam tidak sejalan dengan Hak Asasi Manusia (HAM) tidak bisa dipertahankan. Hal itu karena perlindungan dan peningkatan martabat manusia selalu menjadi prinsip teori politik dan hukum Islam. Walaupun mungkin ada beberapa area perbedaan konseptual antara hukum Islam dan hukum hak asasi manusia internasional, hal ini tidak membuat keduanya tidak kompatibel (bertentangan). Ada yang berpendapat bahwa manusia tidak memiliki hak dalam hukum Islam tetapi mereka hanya untuk tunduk pada perintah Allah. ${ }^{21}$ Pendapat ini menyesatkan, meskipun benar bahwa manusia mesti tunduk kepada perintah-perintah Allah, namun ini tidak berarti bahwa mereka tidak memiliki hak yang melekat dalam hukum Islam. Prinsip legalitas

\footnotetext{
${ }^{19}$ Lihat Baderin, International Human Rights, 5.

${ }^{20} \mathrm{Ibid}, 14$.

${ }^{21}$ E. Rajaee, Islamic Values and Worldview: Khomeyni on Man, the State and International Politics (London: University Press of America, 1983), 42-45.
} 
adalah prinsip fundamental dari hukum Islam di mana semua tindakan dapat dilakukan kecuali yang dilarang oleh sharî́'ah, ${ }^{22}$ yang berarti bahwa manusia memiliki hak-hak yang melekat pada segala sesuatu kecuali untuk hal-hal yang secara khusus dilarang. Pendapat bahwa semua manusia tidak memiliki hak kecuali kewajiban (takliff) terhadap Allah, ini merupakan ungkapan prinsip ilegalitas, yang membuat hidup tidak dinamis dan sulit. Maka hal ini tidak konsisten dengan tujuan keseluruhan sharî‘'ah yaitu maqâsid al-sharî'ah, yang merupakan realisasi kesejahteraan manusia. ${ }^{23}$

Pandangan keempat, sebagian besar bangsa Muslim yang mendukung pandangan bahwa Islam tidak sesuai dengan konsep hak asasi manusia (HAM) sebenarnya tidak benar-benar bertentangan. Posisi mereka hanya mencerminkan kekecewaan terhadap hegemoni Barat dan juga terhadap setiap ideologi yang dianggap sebagai propaganda Barat, atau menganggap bahwa ini adalah "standar ganda" Barat.

Pandangan kelima bahwa hak asasi manusia internasional mempunyai agenda tersembunyi yaitu anti-agama, merupakan beberapa kecurigaan di kalangan umat Islam. Bahwa setelah adanya pemisahan Gereja dari pemerintahan Amerika di Dunia Barat (yakni suatu fenomena sekulerisasi) dan melalui "perang salib", hak asasi manusia internasional ingin mendiskreditkan keimanan Islam dengan ideologi humanisme internasional, yang bertujuan untuk menghapus agama di dunia.

Varian cara pandang di atas memang tidak bisa dihindari namun ternyata masih terdapat "angin segar" guna melakukan upaya mencari titik temu dengan suatu alibi masih ditemukannya dua pandangan umat Islam yang moderat, pertama: Islam kompatibeldengan hak asasi manusia (HAM) internasional. Atau setidak-tidaknya pandangan yang kedua, yakni hak asasi manusia sebenarnya hanya dapat sepenuhnya direalisir di bawah hukum Islam.

\section{Relasi Hukum Islam dengan Universalisme dalam Hukum Internasional HAM}

Secara tradisional, hukum Islam tidak sepenuhnya berbicara banyak. Ilmu hukum mencocokkan pandangan sumber-sumber pluralistik, yang tidak menghasilkan perbedaan pendapat hukum yang

22 Ibn Qayyim al-Jawzîyah, I'lâm al-Muwaqqi în 'an Rabb al-'Alamîn, Vol. 1 (Beirut: Dâr al-Kutub al-'Ilmîyah, 1966), 71-72.

${ }^{23}$ Baderin, International Human Rights, 5-6. 
cukup signifikan dalam analisis perbandingan hukum. Pada akhirnya hukum adalah hasil dari sumber-sumber dan metode, dan hukum Islam bukan pengecualian terhadap fakta. Hal ini penting karena untuk membedakan antara "sharî‘ ah" sebagai sumber dari mana hukum berasal dan "fiqh" sebagai hasil pemahaman ahli hukum berasal dan diterapkan.

Membedakan antara sharî‘ah dan fiqh sangat penting bagi pemahaman yang tepat tentang sifat hukum Islam. Walaupun salah satu dari istilah sharî́ah dan fiqh sering disebut sebagai hukum Islam, secara teknis mereka tidak sama. Secara harfiah, sharî‘ ah berarti "jalan yang harus diikuti", sementara fiqh berarti "pemahaman". Perbedaan yang signifikan berkenaan dengan argumen hukum Islam dalam adalah:

1. Sharî‘ah sebagai sumber hukum Islam adalah wahyu ilahi yang tidak berubah, sedangkan fiqh sebagai pemahaman, interpretasi, dan penerapan sharî́ah, adalah sebuah produk manusia yang dapat berubah sesuai dengan waktu dan keadaan.

2. Sharî́ah mencakup aspek yang lebih luas, yaitu meliputi aspek moral, hukum, sosial, dan spiritual dari kehidupan umat Islam. Sedangkan sebagian besar figh mencakup aspek hukum atau hukum dari sharî‘ ${ }^{6}$ seperti juga dibedakan dari moral. ${ }^{24}$

Jadi, hukum Islam terdiri dari dua komponen: yaitu 1) wahyu ilahi yang tidak berubah dan disebut sharî́ah, dan 2) interpretasi sharî́'ah dari ahli hukum Islam yang disebut fiqh. ${ }^{25}$ Adapun Sumber-sumber Hukum Islam adalah al-Qur'ân dan Sunnah yang merupakan dua sumber formal dan material hukum Islam yang utama. Al-Qur'ân adalah sumber utama dan diyakini oleh umat Islam sebagai kata-kata yang benar dan tepat dari Allah yang diwahyukan kepada Nabi Muhammad selama 23 tahun sebagai bimbingan kemanusiaan. Adapun Sunnah sebagai sumber hukum yang terdiri dari perkataan, perbuatan, perkataan, dan ketetapan Nabi Muhammad. Sunnah dikembangkan dari kebutuhan untuk penyuluhan yang dilakukan Nabi Muhammad, misalnya untuk menjelaskan tentang beberapa ayat dalam al-Qur'ân.

Penelitian menunjukkan bahwa para ahli hukum Islam klasik telah menggunakan metode hukum Islam (baca: usul fiqh) dalam lingkup

\footnotetext{
${ }^{24}$ M. H. Kamali, Freedom of Expression in Islam (London: Islamic Texts Society, 1997), 27.

${ }^{25}$ Baderin, International Human Rights, 34.
} 
sharî‘ah dengan cara evolusi berdasarkan sebuah konstruksi yang dapat mencegah setiap batasan yang tidak berorientasi atas manusia dan kemanusiaan. Kesadaran mengambil pedoman pokok dan tujuan dari sharî‘ah (maqâsid al-sharîab) yang telah diidentifikasi sebagai peningkatan kesejahteraan manusia (maslahah) dan pencegahan bahaya (mafsadah), merupakan suatu pendekatan holistik yang signifikan untuk mewujudkan lingkup yang tepat dan benar dalam upaya menerapkan hukum Islam.

Berdasarkan uraian di atas, bisa dilihat betapa hubungan hukum Islam dalam upaya untuk menginklusifkan universalisme dan memastikan terealisasinya hak asasi manusia internasional (HAM) pada umat Islam dalam tatanan hukum Internasional. Lebih dari sekadar membangun suatu tatanan agama dan hukum, sharî́ah Islam adalah sebuah prinsip legitimasi di beberapa negara Islam dunia. Banyak rezim Islam di dunia saat ini mencari hak kekuasaan mereka melalui gambaran ketaatan kepada hukum Islam dan tradisi lokal yang berkembang yang tentunya sejalan dengan hukum Islam itu sendiri. Serupa itu, bantuan hukum Islam juga sering terlihat di kalangan internasional hak asasi manusia sebagai bantuan terhadap kemerdekaan, kebebasan, dan hak asasi manusia (HAM) secara umum. Warisan Islam menawarkan banyak pengertian filosofis, nilainilai kemanusiaan, dan prinsip-prinsip moral yang baik diadaptasi untuk digunakan dalam kontrak prinsip-prinsip hak asasi manusia, nilai-nilai, dan prinsip-prinsip tersebut berkembang bahkan sejak masa klasik intelektual Islam. ${ }^{26}$

\section{Sintesa HAM dan Hukum Islam}

Tahun-tahun antara abad ke 9-15 perjalanan sejarah Barat sering disebut sebagai Abad Pertengahan ataupun abad kegelapan (the Dark Age). Dunia Islam kala itu justru tengah berada di puncak kejayaan dalam menyumbangkan ilmu pengetahuan dan peradaban pada dunia. Ibn Rushd telah menyebarkan virus kebangkitan pada masyarakat Eropa dengan pahamnya bahwa manusia di dunia ini memiliki posisi dan tugas yang amat mulia, sebagai wakil Tuhan di muka bumi. Nalar dan wahyu dalam Islam memiliki posisi saling melengkapi, bukan berbenturan. Pendapat Ibn Rushd kala itu tentu merupakan ajaran yang sangat asing dan menohok gereja yang selalu berkonfrontasi dengan sepak terjang para ilmuwan yang pada urutannya mendorong

${ }^{26}$ Ibid., 29. 
lahirnya gerakan humanisme-sekularisme di Barat. Kalau sekarang sebagian sarjana Barat sering memperhadapkan antara hak asasi manusia dan Islam, sesungguhnya hal itu sangat ahistoris. Menurut alQur'ân, Adam sebagai simbol seluruh manusia telah dianugerahi kebebasan dan tugas sebagai khalifah di muka bumi, yang oleh Tuhan tidak pernah dicabut dan diintervensi, namun tetap dituntut tanggungjawab, kalaupun tidak di dunia, nanti akan dituntut di akhirat. Ini menunjukkan betapa besarnya hak dan kebebasan yang diberikan oleh Islam pada manusia. ${ }^{27}$

Meskipun demikian, akhir-akhir ini telah terjadi perdebatan yang panjang antara hukum hak asasi manusia dan hukum Islam. Perdebatan itu menghasilkan kesan seakan-akan Islam tidak pro atau bahkan anti-hak asasi manusia. Di sisi lain, perumusan hak asasi manusia serta kenyataan bahwa penganjur utamanya adalah negaranegara Barat mengesankan bahwa nilai hak asasi manusia seluruhnya berasal dari Barat. Adanya sejumlah perbedaan memang tidak dapat diingkari. Namun yang menjadi masalah perdebatan itu kemudian diliputi semangat saling membela diri dan bukan semangat untuk menghasilkan sebuah titik temu atas berbagai perbadaan yang ada. Semangat ini kemudian menghilangkan kemauan untuk meneliti secara cermat tentang hubungan hukum hak asasi manusia dengan hukum Islam. Hal ini diperburuk oleh keadaan bahwa argumen yang muncul lebih didasarkan pada asumsi-asumsi dan praduga dan bukan didasarkan pada sebuah kajian yang bersifat objektif. Apabila ada rujukan, hal itu dibuat dengan mendasarkan pada beberapa praktik di banyak negara-negara Islam. Padahal, praktik-praktik itu lebih didasarkan pada penafsiran-penafsiran dan bukan hukum itu sendiri. Hal ini kemudian tidak menjawab pertanyaan mendasar apakah Islam pada hakikatnya pro atau tidak pada hak asasi manusia.

Dalam konteks inilah Baderin mencoba menjernihkan perdebatan itu dangan mengkaji secara objektif hubungan antara hukum sharî́ah dan hukum internasional hak asasi manusia. Baderin kemudian menulis karya yang berjudul International Human Rights and Islamic Law ${ }^{28}$ untuk menjawab persoalan apakah hukum Islam cocok dengan hukum internasional hak asasi manusia dan apakah negara Muslim

27 Komaruddin Hidayat, "Kata Pengantar" dalam Mashood A. Baderin, Hukum Internasional Hak Asasi Manusia dan Hukum Islam, terj. Musa Kazhim dan Edwin Arifin (Jakarta: Komisi Nasional Hak Asasi Manusia, 2010), xxi-xxii.

${ }^{28}$ Baca selengkapnya Baderin, International Human Rights. 
dapat memenuhi hukum internasional sementara mereka tetap tunduk pada hukum Islam. Hal itu dilakukan dengan melakukan kajian terhadap dua instrumen utama hak asasi manusia, yaitu Kovenan Internasional Hak Sipil dan Politik (KIHSP) serta Kovenan Internasional Hak Ekonomi, Sosial, dan Budaya (KIHESB). Kajian dilakukan dengan mengeksplorasi setiap pasal dari dua Kovenan tersebut. Konvensi penghapusan segala bentuk diskriminasi terhadap perempuan juga menjadi bahan kajian Baderin dengan eksplorasi terhadap pasal-pasal yang relevan. ${ }^{29}$

Arti penting bagi perdebatan yang terjadi selama ini adalah bahwa karya Baderin tidak didasari semangat untuk membela diri, namun mencari adanya titik temu pada perbedaan-perbedaan yang muncul. Ia berpendapat bahwa perbedaan-perbedaan dapat lebih mudah ditangani apabila konsep hak asasi manusia dibangun dan ditetapkan secara positif dari dalam melalui tema-tema hukum Islam daripada sebagai konsep asing terhadap hukum Islam yang dipaksakan dari luar. Meskipun hak asasi manusia bersifat universal, ada satu ruang untuk penafsiran dalam penerapannya yang dapat mewadahi perbedaan-perbedaan yang ada di dunia. Hal ini misalnya terlihat dalam konsep margin appresiasi (margin of appreciation). Konsep ini ada di dalam rezim hak asasi manusia Eropa yang diartikan sebagai "garis di mana pengawasan internasional memberikan ruang bagi kebijaksanaan negara untuk menegakan hukum internasional yang diratifikasinya". Sebaliknya, seperti dikatakan Baderin, walaupun teks al-Qur'ân yang notabene merupakan sumber hukum Islam tidak mengalami amendemen, ketentuan-ketentuannya bisa ditafsirkan sesuai dengan perubahan-perubahan masyarakat dan prinsip pembenaran yang terkait di dalam nilai-nilai holistik sharî‘ ah melalui cara yang menjamin tiadanya penyimpangan dari landasan-landasan ilahinya. Baderin juga mengutip ungkapan umum dalam hukum Islam yang berbunyi taghayyur al-ạ̣kâm bi taghayyur al-zamân, bahwa putusan-

\footnotetext{
${ }^{29}$ Baca bab tiga dan bab empat dalam Baderin, International Human Rights, 48-168 dan 169-218. Dalam hal itu, negara-negara Muslim yang memberlakukan hukum Islam juga kerap mengajukan argumen-argumen dalam kaitannya dengan universalisme Hukum Islam itu sendiri. Lihat Mashood. A. Baderin, "A Macroscopic Analysis of the Practice of Muslim States Parties to International Human Rights Treaties: Conflict or Congruence?" dalam Human Rights Law Review, Vol. 1, No. 2 (2001), 265-303.
} 
putusan hukum bisa berubah seiring perubahan zaman. Di sinilah ruang untuk mencari titik temu perbedaan-perbedaan itu. ${ }^{30}$

Lebih jauh Baderin menyimpulkan bahwa baik ahli hukum hak asasi manusia internasional maupun ahli fiqh Islam hendaknya mengambil pendekatan yang akomodatif dan saling melengkapi ( $a$ complementary approach) untuk mencapai tujuan peningkatan martabat manusia. Kesimpulan ini menunjukkan terbukanya jalan pencarian bagi titik temu berbagai perbedaan dan bukan justru menutup jalan pencarian dengan membela diri dan mengaku (mengklaim) sebagai yang paling benar. ${ }^{31}$

Dari sini kemudian Baderin mengajukan tawaran konsep konvergensi, yaitu doktrin prinsip dasar Hukum Islam adalah maslahah (kesejahteraan/kepentingan manfaat untuk umum) dan Hak Asasi Manusia (HAM) sebagai pandangan margin apresiasi. ${ }^{32}$ Pendekatan ini merupakan tapal batas (border line) antara HAM Internasional dengan hukum Islam sebagai dasar kesamaan secara bumanis berdasarkan kemanfaatan bersama.

\section{Signifikansi Dialog antara Hukum Internasional Hak Asasi Manusia dan Hukum Islam}

Butir lima Deklarasi Vienna dan Program Aksi menyatakan, "semua hak asasi manusia adalah universal, tidak dapat dipisahkan, saling bergantung dan saling terkait. Masyarakat internasional secara umum harus memperlakukan hak asasi manusia di seluruh dunia secara adil dan seimbang, dengan menggunakan dasar dan penekanan yang sama. Sementara kekhususan nasional dan regional serta berbagai latar belakang sejarah, budaya, dan agama adalah sesuatu yang penting dan terus menjadi pertimbangan, adalah tugas semua negara, apapun sistem politik, ekonomi dan budayanya, untuk

\footnotetext{
${ }^{30}$ Baderin, International Human Rights, 6. Dalam kaitannya dengan margin of appreciation Baderin menyatakan bahwa di satu sisi Hukum Islam dituntut merujuk pada yurisprudensi komite HAM dan penjabaran-penjabaran ilmiah lain yang menjelaskan kovenan internasional tentang hak-hak sipil dan politik sebagaimna yang ditafsirkan menurut hukum HAM internasional. Pada sisi yang lain, Hukum Islam tetap merujuk pada sumber utama hukum Islam (al-Qur'ân dan Sunnah) serta pandangan-pandangan fuqahâ' mengenai perspektif Islam. Baderin, "A Macroscopic Analysis", 265-303.

${ }^{31}$ Ibid., 219-222.

32 Ibid., 6.
} 
memajukan dan melindungi semua hak asasi manusia dan kebebasan asasi". ${ }^{33}$

Butir lima Deklarasi Vienna di atas menegaskan beberapa hal. Pertama, semua hak asasi manusia baik itu hak-hak sipil politik maupun hak-hak ekonomi, sosial, dan budaya adalah universal, tidak dapat dipisahkan, saling bergantung dan saling terkait. Itu berarti bahwa suatu negara tidak bisa mengedepankan pemajuan dan perlindungan suatu kelompok hak asasi manusia (HAM) semisal hakhak sipil politik dan mengesampingkan kelompok HAM lainnya, semisal hak-hak ekonomi, sosial dan budaya, demikian pula sebaliknya. Kedua kelompok HAM ini tidak terpisahkan, saling bergantung dan saling terkait. Masyarakat dunia harus memperlakukan semua HAM secara adil dan seimbang, dengan menggunakan dasar dan penekanan yang sama. Kedua, bahwa kekhususan nasional dan regional serta berbagai latar belakang sejarah, budaya, dan agama adalah sesuatu yang penting dan harus terus menjadi pertimbangan dalam memajukan dan melindungi semua HAM. Ketiga, adalah tugas semua negara, apapun sistem politik, ekonomi, dan budayanya, untuk memajukan dan melindungi semua HAM dan kebebasan asasi. ${ }^{34}$

Hal kedua yang ditekankan oleh butir lima Deklarasi Vienna menegaskan, bahwa meskipun HAM diterima oleh semua negara sebagai sesuatu yang universal, namun dalam pelaksanaan dan perlindungan HAM harus terus-menerus mempertimbangkan berbagai kekhasan, baik yang muncul pada tingkat nasional, regional, maupun yang timbul karena faktor-faktor sejarah, budaya, dan agama. Kekhasan-kekhasan yang ditimbulkan oleh berbagai faktor itulah yang melahirkan berbagai konsep dan penafsiran tentang Hukum Internasional Hak Asasi Manusia (HIHAM) yang tentu saja membawa pengaruh pada pengamalan HAM.

33 Teks asli butir lima Deklarasi Vienna sebagai berikut:

"All human rights are universal, indivisible, interdependent and interrelated. The international community must treat human rights globally in a fair and equal manner, on the same footing, and with the same emphasis. While the signivicance of national and regional particularities and various historical, cultural and religious backgrounds must be borne in mind, it is the duty of States, regardless of their political, economic and cultural systems, to promote and protect all human rights and fundamental freedoms". Lihat Abdul Hakim Garuda Nusantara, "Kata Pengantar" dalam Baderin, Hukum Internasional Hak Asasi Manusia dan Hukum Islam, terj. Musa Kazhim dan Edwin Arifin (Jakarta: Komisi Nasional Hak Asasi Manusia, 2010), xi-xii.

${ }^{34}$ Ibid. 
Inilah kepedulian Baderin dalam menulis bukunya tentang Hukum Internasional HAM dan Hukum Islam. Sebuah buku yang mendialogkan Hukum Internasional HAM dengan Hukum Islam dengan tujuan untuk membangun pemahaman bersama tentang hakhak dan kebebasan manusia. Memang benar, bila sejumlah pakar dan para aktivis lebih menyoroti peristiwa-peristiwa pelanggaran HAM dengan menggunakan HIHAM sebagai dasar rujukan hukum. Dengan merujuk pada HIHAM itu para pakar dan aktivis mendesak negara dan PBB untuk mematuhi hukum internasional tersebut. Advokasi seperti itu sudah pasti berguna. Namun suatu upaya untuk membangun pemahaman bersama tentang HAM yang digali dari berbagai budaya, pandangan dan pengalaman itu tidak saja penting tetapi sangat berguna untuk memperkaya konsep HAM, kesadaran berbudaya HAM, yang pada akhirnya akan menyokong bagi efektivitas pemajuan dan perlindungan HAM di tingkat nasional, regional, dan global.

Ada sejumlah alasan mengapa perlu dialog yang terus-menerus antara HIHAM dan Hukum Islam. Pertama, sebagaimana dikemukakan oleh Baderin, bahwa banyak negara anggota PBB adalah negara Muslim yang memberlakukan hukum Islam baik secara menyeluruh atau sebagian hukum domestik. Hukum Islam dengan demikian melalui berbagai cara mempengaruhi gaya hidup milyaran manusia di seluruh dunia. Fakta ini saja sudah dengan sendirinya menunjukkan pengaruh Hukum Islam terhadap pengamalan HAM. Kedua, negara-negara Muslim anggota PBB (Perserikatan Bangsa Bangsa) bekerjasama untuk mewujudkan tujuan pemajuan dan perlindungan HAM Internasional, akan tetapi mereka juga mengemukakan deklarasi dan keraguan dengan mendasarkan pada sharî́ah atau hukum Islam ketika mereka meratifikasi traktat-traktat internasional hak asasi manusia. Hal itu dapat dilihat pada laporanlaporan periodik mereka untuk badan-badan perjanjian (treaty bodies) dan piagam PBB di mana negara-negara Muslim merujuk pada sharî‘ah atau hukum Islam dalam argumen mereka. Ketiga, adanya pandangan umum di Barat yang keliru atau tidak akurat tentang Hukum Islam yang dinilai tidak sesuai dengan HIHAM. Adanya persepsi umum yang tidak tepat di Barat mengasumsikan seolah-olah pelaksanaan dan perlindungan HAM tidak efektif dalam sistem Hukum Islam. ${ }^{35}$

35 Ibid., 15. 
Dialog yang terus-menerus dalam prinsip keseteraan kedua sistem hukum, yaitu sistem hukum HIHAM dan sistem Hukum Islam akan membuka peluang yang luas bagi terwujudnya pemahaman bersama tentang HAM yang pada gilirannya akan memudahkan tercapainya efektivitas pelaksanaan dan perlindungan HAM. Dengan begitu akan membuka peluang lebih besar bagi terwujudnya kemaslahatan dan kesejahteraan manusia.

\section{Wujud Pengakuan HAM dan Hukum Islam terhadap Karâmah Insânîyah LGBT ${ }^{36}$}

Manusia diciptakan dengan jenis kelamin laki-laki dan perempuan. Namun pada realita yang berkembang dalam masyarakat modern saat ini telah banyak ditemui problematika pergantian kelamin. Sudah bukan rahasia umum lagi, banyak individu masyarakat yang merubah kelaminnya dengan berbagai alasan. Contohnya seorang yang berkelamin laki-laki namun dalam jiwanya ia adalah seorang wanita, begitupula sebaliknya. Laki-laki yang berpenampilan layaknya wanita, begitupula sebaliknya. Ada pula orang yang berkelamin ganda, yaitu wanita dan pria yang tidak jelas apakah status atau jenis kelamin yang sebenarnya. Fenomena ini dikenal dengan istilah transgender. Transgender adalah istilah yang digunakan untuk mendeskripsikan orang yang melakukan, merasa, berpikir, atau terlihat berbeda dari jenis kelamin yang sejak lahir mereka dapatkan. Dalam lingkungan masyarakat, kelompok transgender sering dikucilkan dan menjadi bahan olokan bahkan bahan pembicaraan sehingga transgender belum dapat di terima oleh lingkungan masyarakat. Contoh kasus transgender yang masih hangat saat ini adalah perkara transgender di Pengadilan Negeri Makassar, di mana seseorang mengajukan permohonan untuk mengubah jenis kelaminnya ke Pengadilan Negeri setempat dan dikabulkan dengan mempertimbangakan berbagai aspek. ${ }^{37}$ Dengan contoh kasus yang

\footnotetext{
36 Baderin hanya menyinggung sekilas perihal status LGBT, itupun yang disebut hanya "homosexuality", yaitu di halaman 117, 231, dan 234. Bahan yang komprehensif untuk menyajikan kasus LGBT penulis temukan pada laporan hasil dokumentasi acara Komunitas LGBT Nasional Indonesia yang diselenggarakan pada 13-14 Juni 2013 di Bali yang ditulis Dede Oetomo dan Khanis Suvianita, Hidup sebagai LGBT di Asia: Laporan Nasional Indonesia: Tinjauan dan Analisis Partisipatif tentang Lingkungan Hukum dan Sosial bagi Orang dan Masyarakat Madani Lesbian, Gay, Biseksual, dan Transgender: LGBT (Bali: USAID-UNDP, 2013).

${ }^{37}$ Kasus ini menimpa seorang mahasiswi kota Makassar yang bernama Sri Wahyuni yang ingin mengganti jenis kelaminnya menjadi lelaki. Setelah mendengar kesaksian
} 
demikian bukan berarti pemenuhan hak-hak terhadap transgender menjadi lebih mudah, masih ada hal-hal yang sampai saat ini masih menjadi perdebatan di Indonesia bahkan di dunia internasional khususnya terkait HAM. ${ }^{38}$

Menurut Eko Riyadi, Selaku Direktur PUSHAM UII, di dunia internasional transgender masuk dalam kategori LGBTIQ ${ }^{39}$ (Lesbian Gay Bisexual Transgender Intersexual Querr). Istilah LGBTIQ pada mulanya hanya terdiri dari LGB, sebagai simbolisasi dari orientasi seksual di luar "normal". Homoseksual adalah orientasi seksual di mana seseorang memiliki ketertarikan seksual kepada sesama jenis kelaminnya. Lesbian merupakan istilah untuk homoseks perempuan, Gay untuk homoseks laki-laki, dan Biseksual adalah orientasi seksual di mana seseorang memiliki ketertarikan, baik kepada laki-laki maupun perempuan. Sedangkan Transgender mempunyai pengertian merubah jenis kelamin dari jenis kelamin yang diterima sejak lahir ke jenis kelamin barunya. Istilah transgender menjadi bagian pembahasan dalam lingkup yang sama dengan LGBTIQ, tidak bisa disendirikan. Ini artinya, bila ingin membahas soal transgender harus dilakukan secara keseluruhan, karena kesemuanya jika ditinjau dari sudut pandang HAM mempunyai keterkaitan satu sama lain. Istilah LGB yang mulai digunakan pada 1990-an kemudian mengalami perkembangan dengan hadirnya pergerakan waria, sehingga istilahnya menjadi LGBT. Saat ini, istilah yang umum digunakan adalah LGBTIQ (Lesbian Gay Bisexual Transgender Intersexual Querr), dengan tambahan intersexual yang merujuk pada keadaan di mana seseorang secara fisik maupun psikologis berada di antara dua jenis kelamin dan queer sendiri mempunyai pengertian perangkat berpikir terlepas dari orientasi seksual dan indentitas. Dengan demikian querr dimaknai sebagai orang yang pola berpikirnya di luar kerangka laki-laki maupun perempuan; jadi lebih ke kerangka berpikirnya, bukan orientasi

dari para ahli di bidangnya dan melakukan pertimbangan-pertimbangan, akhirnya diputuskan untuk mengabulkan permohonannya. Keputusan PN Makssar ini dibacakan oleh hakim Muh. Damis pada hari senin tanggal 1 September 2014. http://m.suara.com/news/2-September-2014/diakses 21-November-2015.

38 Oetomo dan Suvianita, Hidup sebagai LGBT di Asia, 33. Lihat juga Veni Dwi Puspitadewi dan Rizky Aedeta Putra, "Transgender dalam Pandangan Hak Asasi Manusia" dalam http://pkbh.uii.ac.id/news/latest/.html/26-Agustus-2015/diakses 17-November-2015.

39 Selanjutnya term LGBT dan LGBTIQ akan digunakan secara bergantian dalam pengertian yang sama. 
seksualnya. Kalau lesbian dan gay lebih pada ke orientasi seksual; transgender bukan orientasi seksual tapi dapat dikatakan bahwa dalam dirinya ada jiwa lain sehingga kadang terdengar kiasan "wanita yang terjebak dalam tubuh laki-laki". Adapun gender yang memayungi semua label seksual dan gender minoritas lainnya seperti panseksual (ketertarikan seksual kepada semua gender, termasuk kepada transgender), demiseksual (ketertarikan seksual kepada orang yang memiliki kedekatan secara emosional), dan aseksual (tidak memiliki ketertarikan seksual sama sekali). ${ }^{40}$

Transgender sendiri dapat dibedakan menjadi dua macam. Pertama, transgender karena faktor medis/biologis yang terdapat dalam diri seseorang atau dapat dikatakan terjadi secara natural. Transgender jenis ini seperti seseorang yang berkelamin ganda namun gender yang menonjol satu jenis kelamin. Contohnya kasus seseorang yang terlahir dengan jenis kelamin perempuan namun seiring bertambahnya umur muncul semacam tonjolan-tonjolan di tengahtengah alat kelamin wanitanya dan lama kelamaan membentuk alat kelamin laki-laki. Pada saat berumur 18 tahun ia memutuskan untuk melepas jilbabnya karena merasa dirinya laki-laki. Fenomena seperti itu memang muncul dari faktor dalam diri manusia secara alamiah karena dapat dideteksi secara medis melalui pengecekan baik dilakukan dengan melihat kondisi fisiknya maupun dengan cara yang lebih canggih melalui tes kromosom. Oleh karenanya, seseorang yang berkelamin ganda karena faktor medis dapat memilih jenis kelamin yang lebih dominan dalam dirinya. Kedua, transgender "tidak natural". Dengan kata lain, dilihat secara fisik ia sempurna dengan jenis kelamin laki-laki ataupun wanita. Jenis transgender kedua ini terjadi karena adanya dorongan dalam jiwa untuk merubah jenis kelaminnya, bukan karena alasan biologis maupun fisik. ${ }^{41}$

${ }^{40}$ Veni Dwi Puspitadewi dan Rizky Aedeta Putra, "Transgender dalam Pandangan Hak Asasi Manusia" dalam http://pkbh.uii.ac.id/news/latest/.html/26-Agustus2015/ diakses 17-November -2015.

41 Bagaimana hukum di Indonesia secara umum memaknai problematika transgender? Secara internasional, Indonesia hanya mengakui dua jenis identitas manusia, laki-laki dan perempuan. Sedikit sekali negara yang mengakui legalitas jenis kelamin di luar dua itu. Walaupun sempat terjadi kehebohan yang terjadi di negara bagian Amerika Serikat terkait transgender yang melangsungkan pernikahan dan mempunyai anak. Masalah muncul ketika orangtua kebingungan dalam menjelaskan siapakah yang ayah atau siapakah yang ibu. Memang sebagian besar negara di dunia hanya mengakui dua identitas laki-laki dan perempuan. Negara yang memperbolehkan seseorang untuk mengubah jenis kelamin contohnya Thailand. 
Dalam kaca mata Hukum HAM Internasional, diskursus transgender masih menjadi perdebatan. Pada dasarnya, menurut HAM Internasional, menghargai kedaulatan orang atas tubuhnya yang kemudian dikenal dengan hak sipil menjadi sesuatu yang paling pokok. Artinya, setiap orang berdaulat atas tubuhnya masing-masing. Mengacu pada filosofi ini, muncullah apa yang disebut hak sipil. Hak sipil sendiri mempunyai pengertian kebebasan individu dari intervensi yang datang dari luar dirinya. Misalnya bebas untuk memilih sesuatu, makan, memilih partai, agama, dan lain sebagainya. Hal ini dinamakan hak sipil karena substansinya pada kebebasan individu dari intervensi yang datang dari luar dirinya. Untuk kasus LGBT/LGBTIQ yang banyak digunakan adalah paradigma di atas tadi. Namun secara internasional perdebatan mengenai isu tersebut belum selesai. Dalam ranah sosial politik, ekonomi, dan budaya, secara umum antara LGBT dengan orang yang lain itu sama. Pada level ini, hak tersebut tidak dapat diganggu gugat.

Sesuatu yang masih menjadi perdebatan sampai sekarang adalah soal identitas bagi kelompok LGBT, apakah negara harus mengakui mereka memiliki identitas lain selain laki-laki dan perempuan. Pada tataran inilah Baderin mengistilahkan dengan margin of appreciation, di mana aspek lokal/regional, budaya, ataupun agama yang mengaturnya. Dengan kata lain, sikap HAM terhadap aspek "kemanusian" kelompok LGBT sudah tidak ada masalah. Demikian pula di mata agama-atau dalam kaca mata legal formal hukum Islam yang landasan filosofinya adalah kemaslahatan-mereka tetap mendapatkan karâmah insâniyah (buman dignity) sampai kapanpun. Mereka mendapatkan hak-hak sipilnya sebagaimana mestinya, seperti hak berpolitik, hak memilih dan dipilih. Agama dan juga kultur hanya tidak dapat menerima perilaku seksual dari kaum lesbian, gay, dan biseksual yang dianggap menyimpang, dan hal ini berbeda dengan kasus transgender seperti yang telah dibicarakan. Tegasnya, karena mereka telah mendapat legitimasi karâmah insânîyah, mereka tidak boleh dimarjinalkan, aparatur negara harus melindungi eksistensinya, mereka harus diberdayakan dan dibimbing ke arah kehidupan yang "normal". Bila setelah diperlakukan dengan baik oleh negara ternyata mereka masih "menyimpang" tentu mereka mendapatkan perlakuan yang sama di muka hukum (equality before the law).

Sedangkan negara yang melegalkan perkawinan sesama jenis adalah Belanda dan salah satu negara bagian di Amerika Serikat. Lihat ibid. 


\section{LBGT dalam Sorotan Hukum Positif Indonesia}

Untuk lebih melengkapi kajian ini, ada sebuah pertanyaan fundamental yang perlu diajukan, yakni apakah Hukum Positif Indonesia dapat melegalkan transgender? Tentu tidak mudah menjawab pertanyaan ini. Namun yang jelas, perjuangan komunitas LGBT sebenarnya hanyalah menyoal tentang identitas bahwa mereka adalah lesbian, gay, biseksual, transgender yang diformalkan; akan tetapi bisa jadi berubah. Menurut hemat penulis, negara sebaiknya tidak usah dan tidak perlu memberikan legalisasi bagi kelompok LGBT dan tidak memberikan legalitas bagi pernikahan sesama jenis, setidaknya sampai saat ini. Pertimbangan yang paling besar terletak pada faktor agama, mengingat agamalah yang paling berperan untuk tidak membenarkan perilaku homoseksual dan perilaku yang menyimpang lainnya. Kalaupun ada orang yang kemudian masuk dalam ketegori LGBT, tentu hal ini adalah pilihan hidup yang harus dihargai. Tidak manusiawi bila mereka mendapat perlakukan bullying apalagi sampai mengutuknya. Dalam pernikahan normal, pernikahan itu perlu dilegalisasi karena salah satu tujuannya adalah untuk menjamin hak-hak para pihak yang ada di dalamnya terutama hak anak; sedangkan untuk kasus pernikahan sesama jenis tidak mungkin mewujudkan kehadiran anak kecuali melalui proses adopsi. Meski demikian, perdebatan untuk hal tersebut memang tidak akan ada habisnya, sehingga untuk hak-hak sipil, negara harus terus menjamin jangan sampai terjadi diskriminasi di dalamnya.

\section{Penutup}

Warisan Islam menawarkan banyak pengertian filosofis, nilai-nilai kemanusiaan, dan prinsip-prinsip moral yang baik diadaptasi untuk digunakan dalam kontrak prinsip-prinsip hak asasi manusia. Nilai-nilai dan prinsip-prinsip tersebut terus berkembang bahkan pada masa klasik intelektual Islam. Salah satu pemikir kontemporer Muslim dari University of London yang bernama Mashood A. Baderin mencoba mengawinkan dialektika pemikiran HAM internasional dan Hukum Islam yang memotret hukum internasional hak asasi manusia dan hukum Islam dalam prinsip kesetaraan dan adanya kesamaan prinsip dasar (margin of appreciation) yang harus dijunjung tinggi dalam mewujukan hak asasi manusia dalam konteks penerapan hukum Islam di negara-negara Muslim dan penerapan hukum internasional hak asasi manusia di negara-negara Barat, termasuk di dalamnya adalah fenomena LGBT. 
Baderin menegaskan teorinya, bahwa pandangan hukum Islam selaras dengan Hukum Internasional Hak Asasi Manusia bukanlah sekadar sikap apologetik terhadap ideologi Barat. Keselarasan hukum Islam dan HAM Internasional itu karena adanya kesamaan margin of appreciation dan kesamaan tapal batas (border line) antara HAM Internasional dengan maqâsid al-sharîah dalam hukum Islam yang dijadikan sebagai dasar kesamaan secara bumanis dan dalam pijakan kemanfaatan bersama.

Berdasarkan temuan Mashood, kaum LGBT tetap mendapatkan posisinya yang mulia dari sisi kemanusiannya (karâmah insânîyah). Oleh karena itu hak-hak sipil harus tetap melekat pada mereka. Perlakuan diskriminatif dan tindakan-tindakan bulliying lainnya harus dihindarkan dari kehidupan mereka. Mereka dapat hidup berdampingan secara harmonis bersama-sama masyarakat lainnya. Soal orientasi seksual mereka yang masih bertentangan dengan ajaran agama (Islam), tidak menghalanginya untuk mendapatkan bimbingan dan pengarahan dari aparatur negara sebagaimana mestinya. Khusus untuk transgender, mereka berhak mendapatkan pelayanan dari negara melalui jalur pengadilan sampai mereka menemukan jati diri yang sebenarnya.

\section{Daftar Rujukan}

\section{A. Buku}

Baderin, Mashood A. International Human Rights and Islamic Law. New York: Oxford University Press, 2003.

----. "A Macroscopic Analysis of the Practice of Muslim States Parties to International Human Rights Treaties: Conflict or Congruence?" dalam Human Rights Law Review, Vol. 1, No. 2, 2001.

Choir, Tholhatul dan Fanani, Ahwan (eds.). Islam dalam Berbagai Pembacaan Kontemporer. Yogyakarta: Pustaka Pelajar, 2009.

Halliday, F. "Relativism and Universalism in Human Rights: The Case of the Islamic Middle East", dalam D. Beetham (ed.), Politics and Human Rights. Oxford: Blackwell, 1995.

Hidayat, Komaruddin. "Kata Pengantar" dalam Mashood A. Baderin, Hukum Internasional Hak Asasi Manusia dan Hukum Islam, terj. Musa Kazhim dan Edwin Arifin. Jakarta: Komisi Nasional Hak Asasi Manusia, 2010.

Jawzîyah (al), Ibn Qayyim. I'lâm al-Muwaqqi în 'an Rabb al-'Alamin, Vol. 1. Beirut: Dâr al-Kutub al-'Ilmîyah, 1966. 
Kamali, M. H. Freedom of Expression in Islam. London: Islamic Texts Society, 1997.

Lopa, Baharuddin. Al-Qur'ân dan Hak-hak. Asasi Manusia. Yogyakarta: Dana Bhakti Prima Yasa, 1999.

Mortimer, E. "Islam and Human Rights", Index on Censorship, No. 12, Oktober, 1983.

Nusantara, Abdul Hakim Garuda. "Kata Pengantar" dalam Baderin, Hukum Internasional Hak Asasi Manusia dan Hukum Islam, terj. Musa Kazhim dan Edwin Arifin. Jakarta: Komisi Nasional Hak Asasi Manusia, 2010.

Oetomo, Dede dan Suvianita, Khanis. Hidup sebagai LGBT di Asia:

Laporan Nasional Indonesia: Tinjauan dan Analisis Partisipatif tentang Lingkungan Hukum dan Sosial bagi Orang dan Masyarakat Madani Lesbian, Gay, Biseksual, dan Transgender LGBT. Bali: USAIDUNDP, 2013.

Oetomo, Dede. "Pemerintah Dinilai Tak Dukung LGBT Karena Enggan Rugi" dalam http://www.cnnindonesia.com/1-Mei2015/diakses 21 November 2015.

Rajaee, E. Islamic Values and Worldview: Khomeyni on Man, the State and International Politics. London: University Press of America, 1983.

Tibi, Bassam. "Islamic Law/Syariah and Human Rights: International Law and International Relations" dalam Tori Lindholm and Kari Vogt (eds.), Islamic Law Reform and Human Rights: Challenges and Rejoinders. Oslo: Nordic Human Rights Publications, 1993.

\section{B. Internet}

http://m.suara.com/news/2-September-2014/diakses 21-November2015.

http://www.oup.com/us/catalog/general/subject/Law/PublicIntern ationalLaw/InternationalHumanRights/diakses 24 Juli 2016.

Shalahuddin, Henri. "Menyongsong Kebangkitan Kaum Nabi Luth di Indonesia" dalam http://thisisgender.com/9-Februari-2015/ diakses 21 November 2015.

Puspitadewi, Veni Dwi dan Putra, Rizky Aedeta. "Transgender dalam Pandangan Hak Asasi Manusia" dalam http://pkbh.uii.ac.id/news /latest/.html/ 26-Agustus-2015/, diakses 17-November-2015.

Puspitadewi, Veni Dwi dan Putra, Rizky Aedeta. "Transgender dalam Pandangan Hak Asasi Manusia" dalam http://pkbh.uii.ac.id /news /latest/.html/26-Agustus-2015/ diakses 17-November 2015. 